\title{
Modification of Porous Materials by Saturated Fatty Amine as $\mathrm{CO}_{2}$ Capturer
}

\author{
Maratun Najiha Abu Tahari, Azizul Hakim, Mohamed Wahab Mohamed Hisham, and Mohd. Ambar \\ Yarmo
}

\begin{abstract}
Silica dioxide $\left(\mathrm{SiO}_{2}\right)$ and activated carbon (AC) are the common porous materials being used as $\mathrm{CO}_{2}$ capturer. In this work, saturated fatty amine (octadecylamie,ODA) was evaluated as a potential source of basic sites for $\mathrm{CO}_{2}$ capture. Both commercial $\mathrm{SiO}_{2}$ and $\mathrm{AC}$ were used as preliminary supports in order to study the effect of loading. The amine-modified samples were characterized using $x$-ray diffractometer (XRD), attenuated total reflextance/fourier transform infrared spectroscopy (ATR/FTIR), and Brunauer-Emmet-Teller (BET). Reactivity of solid sorbents towards $\mathrm{CO}_{2}$ was evaluated using isothermal $\mathrm{CO}_{2}$ adsorption by BET technique. This study shows that the order of $\mathrm{CO}_{2}$ adsorption capacity by $\mathrm{SiO}_{2}$ type adsorbents are $25 \mathrm{ODA} / \mathrm{SiO}_{2}>$ $\mathrm{SiO}_{2}>15 \mathrm{ODA} / \mathrm{SiO}_{2}>5 \mathrm{ODA} / \mathrm{SiO}_{2}$ whereas $\mathrm{AC}>5 \mathrm{ODA} / \mathrm{AC}>$ $15 \mathrm{ODA} / \mathrm{AC}>25 \mathrm{ODA} / \mathrm{AC}$ for AC type adsorbents. However, the promotion of ODA compounds on the $\mathrm{AC}$ was not improving the $\mathrm{CO}_{2}$ uptake significantly due to pore blockage and drastic reduction in microporous surface area and pore volume of AC.
\end{abstract}

Index Terms-Adsorption, amine impregnation, $\mathrm{CO}_{2}$ capture.

\section{INTRODUCTION}

Carbon dioxide is one of green house gases, known as main anthropogenic contributors to climate change which has drawn significant attention to researchers in looking to develop strategies for reducing the $\mathrm{CO}_{2}$ emissions and concentration. Increasing concentration of $\mathrm{CO}_{2}$ contributes to global warming and climate changes that give critical effects to environment, infrastructures and human. There were several works reported in reducing $\mathrm{CO}_{2}$ concentration by capture and separate the $\mathrm{CO}_{2}$ gas. There are different unit operations such as liquid absorption [1], [2], solid adsorption [3]-[5], cryogenic techniques [6], and selective diffusion through polymer, metallic or ceramic membranes [7].

The development of solid sorbents has focused on the modification of solid surfaces with usually having amine compounds. The solid sorbents should have a porous structure to be filled with amine compounds to enable the retention of $\mathrm{CO}_{2}$ molecules. The commonly used porous solid

Manuscript received February 5, 2015; revised March 27, 2015. This work was financially and technically supported by Ministry of Higher Education and Universiti Kebangsaan Malaysia for funding this project under research grant number BKBP-FST-K003323-2014, STGL-008-2012, ETP-2013-066, and Centre of Research and Innovation Management (CRIM) for the instruments facilities.

The authors are with the School of Chemical Science and Food Technology, Faculty of Science and Technology, Universiti Kebangsaan Malaysia, 43600 Bangi, Selangor, Malaysia (e-mail: maratunnajiha@gmail.com, azizulhakim2442@gmail.com, hisham5011@gmail.com, and ambar@ukm.edu.my). supports are silica fume [8], zeolite [9], mesoporous silica [2], [7], [10], high-carbon fly ash [11], activated carbon (AC) [12], and hydrotalcyte [13]. However, application of solid sorbents together with octadecylamine (ODA) as $\mathrm{CO}_{2}$ capturer is still limited. Selected porous materials for this study are silica dioxide $\left(\mathrm{SiO}_{2}\right)$ and activated carbon (AC). $\mathrm{SiO}_{2}$ and AC surfaces will be modified with ODA compounds by impregnation method to develop high dispersion of amine and thus will give better $\mathrm{CO}_{2}$ adsorption performance. Hence, the objective of this study is to characterize and explore the effect of ODA compounds supported on the surface of $\mathrm{SiO}_{2}$ and $\mathrm{AC}$ towards $\mathrm{CO}_{2}$ adsorption capacity.

\section{PROCEDURES AND METHODS}

Silica-amine adsorbent was prepared by use of wet impregnation. Firstly, commercial silica dioxide, $\mathrm{SiO}_{2}$ received from Fluka was calcined at $400{ }^{\circ} \mathrm{C}$ for 4 hours in air before impregnated with octadecylamine, ODA (ALDRICH ${ }^{\circledR}$, 97\%). Chloroform, $\mathrm{CHCl}_{3}\left(\mathrm{SYSTERM}^{\circledR}, 99-99.4 \%\right)$ was added to dissolve the ODA. After stirring for 4 hours in a close system, the mixture was rested for 1 hour before sonicate (S 4000-010 Sonicator 4000). The mixture was sonicated for 10 minutes, 10 amplitudes, $3 \mathrm{~W}$ and $1600 \mathrm{~J}$. Evaporation of the used solvent was done in air for overnight and followed by drying at $65{ }^{\circ} \mathrm{C}$ for 1 hour. Total amount of each type of adsorbent is $5.0 \mathrm{~g}$. The weight percent (wt \%) of guest was determined by the amount of amine added per total weight of synthesized adsorbent which is $5.0 \mathrm{~g}$. Example, in the making of $5 \mathrm{wt} \% \mathrm{ODA} / \mathrm{SiO}_{2}, 0.25 \mathrm{~g}$ of octadecylamine, ODA (aldrich ${ }^{\circledR}, 97 \%$ ) was dissolved in $20.0 \mathrm{~g}$ of $\mathrm{CHCl}_{3}$ and $4.75 \mathrm{~g} \mathrm{SiO}_{2}$ added for further 4 hours stirring. This method was repeated for production of carbon-amine adsorbents by replacing the $\mathrm{SiO}_{2}$ with activated carbon, $\mathrm{AC}$ (Fluka). Each porous material was loaded with three different weight percent (wt \%) of ODA which are 5, 15 and 25. The modified $\mathrm{SiO}_{2}$ and unmodified $\mathrm{SiO}_{2}$ were denoted as $5 \mathrm{ODA} / \mathrm{SiO}_{2}, 15$ ODA/SiO $2,25 \mathrm{ODA} / \mathrm{SiO}_{2}$ and $\mathrm{SiO}_{2}$ whereas 5 ODA/AC, 15 ODA/AC, 25 ODA/AC and AC for modified and unmodified AC.

The adsorbents were characterized by FTIR (Perkin Elmer Precisely FTIR Spectrometer), BET (Micromeritics ASAP 2010) and XRD (Bruker AXS D8 Advance). FTIR supported with attenuated total reflectance (ATR) was used to measure functional groups of organic and inorganic compounds without further preparation by using infrared light. Adsorbents were examined on Perkin Elmer Precisely FTIR Spectrometer under pressure on the diamond ATR top plate 
and scanned from 4000 to $650 \mathrm{~cm}^{-1}$.

The XRD diffraction patterns obtained using a Bruker AXS D8 Advance type with $\mathrm{x}$-ray radiation source of $\mathrm{Cu} \mathrm{K} \alpha$ $(40 \mathrm{kV}, 40 \mathrm{~mA})$ to record the $2 \theta$ diffraction angle from $3^{\circ}$ $60^{\circ}$. The synthesized adsorbents were analyzed without further treatment.

The Brunauer-Emmet-Teller (BET) surface areas, pores width and pores volume of the adsorbents were measured from adsorption isotherm. These physical characterizations were carried out by $\mathrm{N}_{2}$ adsorption-desorptio at $77 \mathrm{~K}$ (liquid nitrogen) using a Micromeritics ASAP 2010 instrument. Samples were degassed at $75^{\circ} \mathrm{C}$ for 4 hours before analysis.

$\mathrm{CO}_{2}$ adsorption capacity was measured by BET. $0.3 \mathrm{~g}$ of adsorbent was loaded into special round bottom glass and placed into BET port for degassing under $\mathrm{N}_{2}$ atmosphere and heated up to $75{ }^{\circ} \mathrm{C}$. This temperature was maintained for about 4 hours in order to remove all gasses and moisture on the surface of adsorbents. After degassing, the adsorbents were analyzed by using $\mathrm{CO}_{2}$ atmosphere at $25^{\circ} \mathrm{C}$.

\section{RESULTS AND DISCUSSIONS}

\section{A. Characterization of Synthesized Adsorbents}

FTIR with attenuated total reflectance is an excellent technique to obtain structural information of the synthesized adsorbents as shown in Fig. 1. IR spectra for $\mathrm{SiO}_{2}, 25$ $\mathrm{ODA} / \mathrm{SiO}_{2}$ and ODA are displayed on Fig 1a. Modified $\mathrm{SiO}_{2}$ denoted as $25 \mathrm{ODA} / \mathrm{SiO}_{2}$ shows vibration of asymmetric $\left(v_{a}\right)$ and symmetric $\left(v_{s}\right) \mathrm{N}-\mathrm{H}$ stretches of primary amine at 3360 and $3325 \mathrm{~cm}^{-1}$ in Fig. 1b. These vibration bands have much weaker intensity compared to the bulk ODA and this is due to the small amount of ODA compounds being impregnated on the $\mathrm{SiO}_{2}$.

Referring to the Fig. 1c, the main peaks around 2930 and $2850 \mathrm{~cm}^{-1}$ are respectively assigned to the asymmetric $\left(v_{a}\right)$ and symmetric $\left(v_{s}\right)-\mathrm{CH}_{2}-$ stretching of ODA alkyl skeleton [14]. Besides, much weaker bands at 3000 and $2875 \mathrm{~cm}^{-1}$ are corresponding to vibrations of asymmetric $\left(v_{a}\right)$ and symmetric $\left(v_{s}\right)-\mathrm{CH}_{3}$ stretches end groups. These bands are very close to those of $-\mathrm{CH}_{3}$ absorption bands as stated by [14]. A shoulder roughly at $2895 \mathrm{~cm}^{-1}$ is due to Fermi resonance between the symmetric $-\mathrm{CH}_{2}-$ stretching and the overtones of the methylene scissoring [15].

Moreover, methylene rocking vibration on Fig. 1d appears as sharp and strong band at $718 \mathrm{~cm}^{-1}$ could be attributed to both ODA and modified $\mathrm{SiO}_{2}$. However, an out-of-plane (oop) $\mathrm{N}-\mathrm{H}$ bending vibration of $25 \mathrm{ODA} / \mathrm{SiO}_{2}$ shows as broad band instead of sharp band as in ODA spectrum. This is due to overlapping of N-H (oop) with $\mathrm{Si}-\mathrm{O}-\mathrm{Si}$ symmetric stretching $\left(v_{s}\right)$ of $\mathrm{SiO}_{2}$. The $\mathrm{C}-\mathrm{N}$ stretching absorption occurs at $1160 \mathrm{~cm}^{-1}$ as strong band with lower intensity in ODA spectrum. The presence of this group in the modified $\mathrm{SiO}_{2}$ sample causes the broad absorption band around $1250-860$ $\mathrm{cm}^{-1}$ became intense. This is owing to the overlapping of the $\mathrm{C}-\mathrm{N}$ stretching absorption with $\mathrm{Si}-\mathrm{O}-\mathrm{Si}\left(v_{s}\right)$. The existence of $-\mathrm{CH}_{2}$ deformation of alkyl chain structural arrangement at 1473 and $1465 \mathrm{~cm}^{-1}$ are further confirm the presence of dispersed ODA on $\mathrm{SiO}_{2}$ surfaces [16]. A strong and broad band at $1567 \mathrm{~cm}^{-1}$ is associated to $-\mathrm{NH}_{2}$ bending vibration of primary amine [17]. Besides, two absorption bands of asymmetric and symmetric deformation of $-\mathrm{NH}^{3+}$ exist at 1643 and $1485 \mathrm{~cm}^{-1}$ on the ODA spectrum.
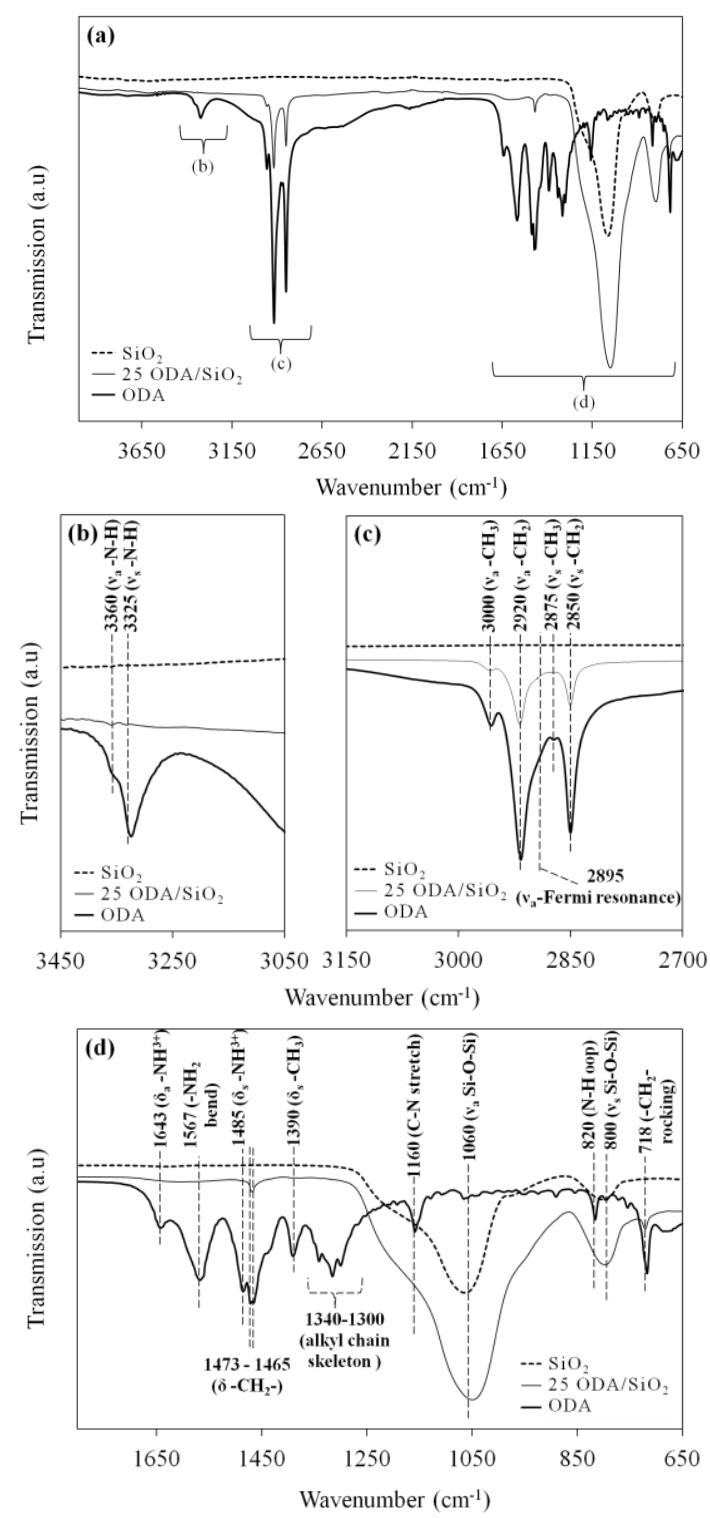

Fig. 1. ATR/FTIR spectra of ODA, $\mathrm{SiO}_{2}$, and $25 \mathrm{ODA} / \mathrm{SiO}_{2}$ in (a) overall spectra, (b) at range $3450-3050 \mathrm{~cm}^{-1}$, (c) $3150-2700 \mathrm{~cm}^{-1}$, and (d) $1800-$ $650 \mathrm{~cm}^{-1}$.

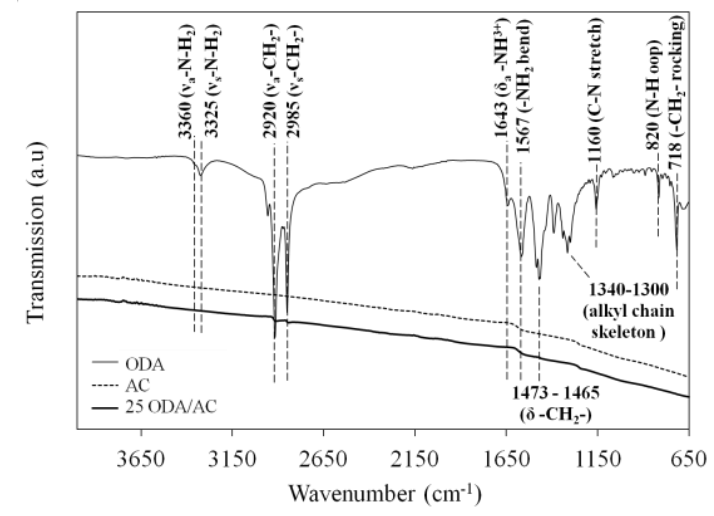

Fig. 2. ATR/FTIR spectra of ODA, AC, and $25 \mathrm{ODA} / \mathrm{AC}$ in the range of $4000-650 \mathrm{~cm}^{-1}$.

Fig. 2 shows ATR/FTIR spectra for ODA, AC and 25 ODA/AC. There is no peak detected on the AC spectrum, 
which is explained that the $\mathrm{AC}$ material is absence from any foreign molecules. In the case of $25 \mathrm{ODA} / \mathrm{AC}$ spectrum, asymmetric and symmetric vibrations of $-\mathrm{CH}_{2^{-}}$stretching were detected at 2920 and $2850 \mathrm{~cm}^{-1}$ associated to the aliphatic of the amines incorporated onto the AC [18]. The presence of these bands referring to the alkyl skeleton of ODA compounds that dispersed on the AC surfaces. Unfortunately, the absorption bands for primary amine around 3360 and $3325 \mathrm{~cm}^{-1}$ on the AC were not appeared. It is due to the difficulties in detecting amine groups as the amount of the $-\mathrm{NH}_{2}$ to the alkyl groups and AC is too small (1:15.8 and $1: 16.8)$. Furthermore, the ability of the ODA compounds to enter the AC pores also contributing to this poor absorption bands detection. Therefore, XRD analysis has been used in order to confirm the presence of ODA on the AC surfaces.

The XRD patterns of $\mathrm{SiO}_{2}$ type adsorbents are shown in Fig. 3a. The calcined $\mathrm{SiO}_{2}$ shows a relatively broad diffraction peak at $2 \theta=21.9^{\circ}$. Addition of ODA on the $\mathrm{SiO}_{2}$ surfaces, denoted as 5 and $15 \mathrm{ODA} / \mathrm{SiO}_{2}$ had little effect on their mesoporous structure as summarized in Table I, as the diffraction patterns remain unchanged after the introduction of small amount amine [19]. However, the broad peak of $\mathrm{SiO}_{2}$ around $2 \theta=16^{\circ}-30^{\circ}$ become weaker and shrink a bit especially for adsorbent with higher ODA loadings. In the case of $25 \mathrm{wt} \%$ ODA loadings, the $2 \theta$ range of broad peak become smaller $\left(18^{\circ}-25^{\circ}\right)$ and the presence of new diffraction peaks with their lattice [010], [100], [-201], [-230], [-221] and [201] in Fig. 3b and 3c proven that the impregnation of ODA on the $\mathrm{SiO}_{2}$ surfaces was successful. These peaks belong to semi crystalline of existence ODA which is closely similar with JCPDS N0. 062-1586.

TABLE I: TEXTURAL PROPERTIES OF $\mathrm{SIO}_{2}$, AC AND ODA-CONTAINING

\begin{tabular}{|c|c|c|c|c|c|c|}
\hline \multicolumn{7}{|c|}{ ADSORBENTS } \\
\hline $\begin{array}{l}\text { Adsor } \\
\text { bents }\end{array}$ & Denotes & $\begin{array}{c}S_{B E T} \\
{\left[\mathrm{~m}^{2} / \mathrm{g}\right]}\end{array}$ & $\begin{array}{c}V_{t} \\
{\left[\mathrm{~cm}^{3} / \mathrm{g}\right]}\end{array}$ & $\begin{array}{l}W_{A} \\
{[\AA]}\end{array}$ & $\begin{array}{c}t \text {-plot } \\
\text { mic } \\
{\left[\mathrm{m}^{2} / \mathrm{g}\right]}\end{array}$ & $\begin{array}{c}t \text {-plot } \\
\text { ext } \\
{\left[\mathrm{m}^{2} / \mathrm{g}\right]}\end{array}$ \\
\hline $\begin{array}{l}\mathrm{SiO}_{2} \\
\text { only }\end{array}$ & $\mathrm{SiO}_{2}$ & $\begin{array}{c}252.4 \\
6\end{array}$ & 1.11 & 170.37 & 20.11 & $\begin{array}{c}232.3 \\
4\end{array}$ \\
\hline $\begin{array}{l}5 \mathrm{wt} \% \\
\mathrm{ODA} / \\
\mathrm{SiO}_{2}\end{array}$ & $\begin{array}{c}5 \\
\mathrm{ODA} / \mathrm{SiO}_{2}\end{array}$ & $\begin{array}{c}211.8 \\
2\end{array}$ & 0.97 & $\begin{array}{c}155.8 \\
9\end{array}$ & ND & $\begin{array}{c}218.2 \\
4\end{array}$ \\
\hline $\begin{array}{c}15 \\
\text { wt } \% \\
\text { ODA/ } \\
\mathrm{SiO}_{2}\end{array}$ & $\begin{array}{c}15 \\
\text { ODA/SiO }\end{array}$ & $\begin{array}{c}137.3 \\
1\end{array}$ & 0.65 & $\begin{array}{c}138.2 \\
8\end{array}$ & ND & $\begin{array}{c}190.3 \\
0\end{array}$ \\
\hline $\begin{array}{c}25 \\
\text { wt } \% \\
\text { ODA/ } \\
\mathrm{SiO}_{2}\end{array}$ & $\begin{array}{c}25 \\
\text { ODA/SiO }\end{array}$ & $\begin{array}{c}114.6 \\
7\end{array}$ & 0.41 & $\begin{array}{c}103.2 \\
7\end{array}$ & ND & $\begin{array}{c}168.8 \\
3\end{array}$ \\
\hline $\begin{array}{l}\text { AC } \\
\text { only }\end{array}$ & $\mathrm{AC}$ & $\begin{array}{c}862.7 \\
2\end{array}$ & 0.30 & 40.85 & $\begin{array}{c}483.2 \\
8\end{array}$ & $\begin{array}{c}379.4 \\
4\end{array}$ \\
\hline $\begin{array}{c}5 \mathrm{wt} \% \\
\text { ODA/ } \\
\mathrm{AC}\end{array}$ & $\begin{array}{c}5 \\
\text { ODA/AC }\end{array}$ & $\begin{array}{c}521.1 \\
1\end{array}$ & 0.25 & 41.74 & $\begin{array}{c}228.7 \\
3\end{array}$ & $\begin{array}{c}292.3 \\
8\end{array}$ \\
\hline $\begin{array}{c}15 \\
\text { wt } \% \\
\text { ODA/ } \\
\text { AC }\end{array}$ & $\begin{array}{c}15 \\
\text { ODA/AC }\end{array}$ & $\begin{array}{c}266.6 \\
3\end{array}$ & 0.21 & 45.92 & 37.98 & $\begin{array}{c}228.6 \\
5\end{array}$ \\
\hline $\begin{array}{c}25 \\
\text { wt } \% \\
\text { ODA/ } \\
\text { AC }\end{array}$ & $\begin{array}{c}25 \\
\text { ODA/AC }\end{array}$ & 36.92 & 0.11 & 97.20 & ND & 48.05 \\
\hline
\end{tabular}

$S_{B E T}=$ BET surface area. $V_{t}=$ Total pore volume. $W_{A}=$ BJH Adsorption average pore width. $t$-plot ${ }_{\text {mic }}=t$-plot micropore area. $t$-plot ${ }_{\text {ext }}=t$-plot external surface area. $\mathrm{ND}=$ Not detected.
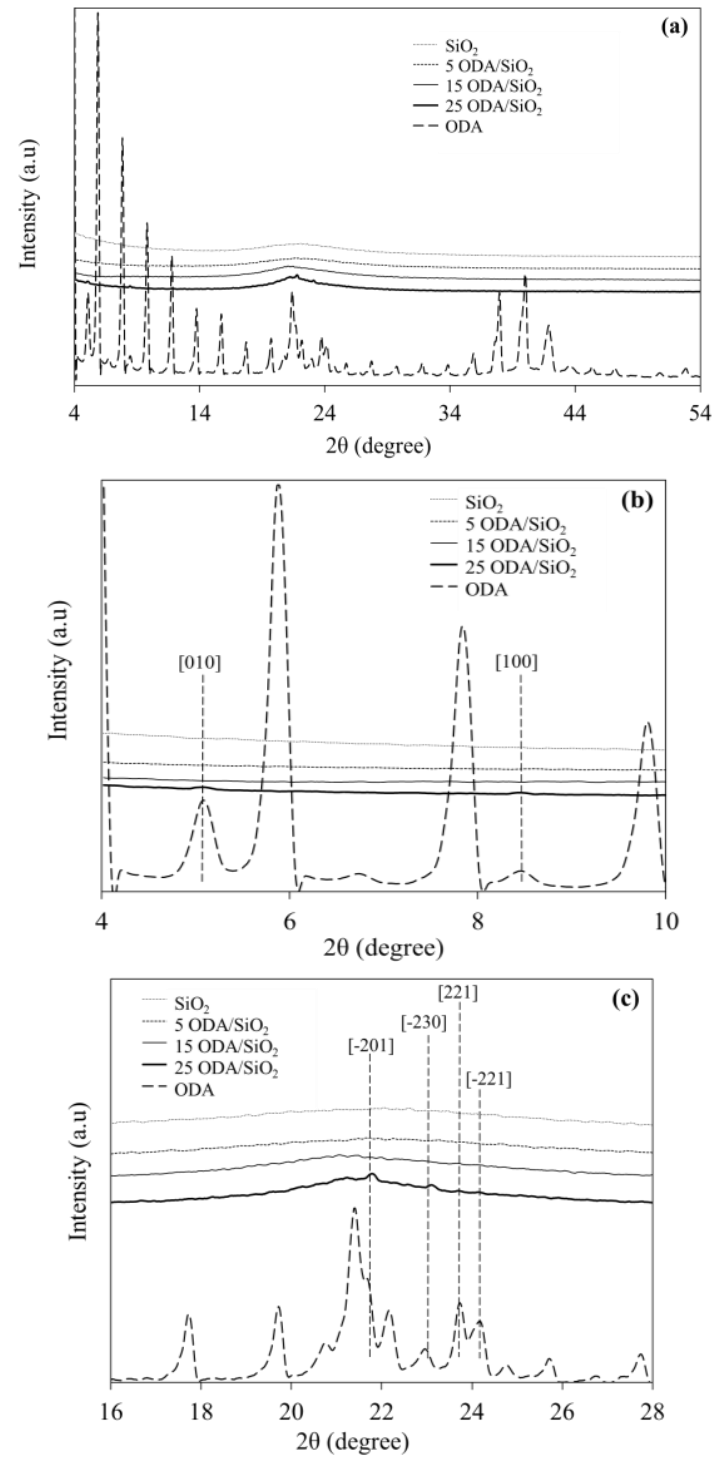

Fig. 3. XRD patterns of ODA, $\mathrm{SiO}_{2}$, and modified $\mathrm{SiO}_{2}$ with different range of degree $(2 \theta)$ as (a) at range $4^{\circ}-54^{\circ}$, (b) $4^{\circ}-10^{\circ}$, and (c) $16^{\circ}-28^{\circ}$.
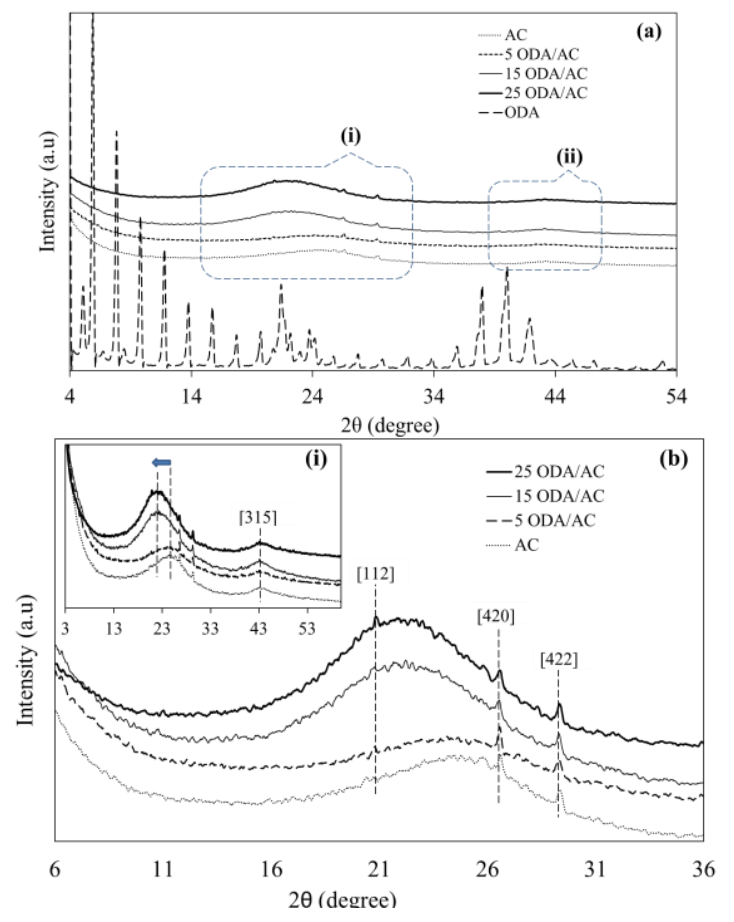

Fig. 4. XRD patterns of ODA, AC, and modified AC with different range of degree $(2 \theta)$ as (a) at range $4^{\circ}-54^{\circ}$, and (b) $6^{\circ}-36^{\circ}$, and (i) $3^{\circ}-53^{\circ}$. 
XRD patterns for AC with different weight percent (wt \%) of ODA loadings are shown on Fig. 4a. Two broad peaks in the rounded rectangular callouts, i.e. (i) and (ii) centered at $2 \theta=26^{\circ}$ and $44^{\circ}$ were detected on the AC diffractogram which characterizing the carbon structure. Intensity of another two sharp peaks $\left(2 \theta=26.7^{\circ}\right.$ and $\left.29.4^{\circ}\right)$ with their lattice around [002] and [422] were reduced with the increasing ODA loadings as illustrated in Fig. 4b. The diffraction peaks intensities can be correlated with the scattering contract between the solid walls and the pores [19]. The higher amount of amine incorporated into the pore channels, the lower the peak intensity will be produced [20], [21]. These proved by the reduction in BET surface area, total pore volume and micropores area of modified $\mathrm{AC}$ as summarized in Table I. Additionally, one peak ascribed to ODA compounds that dispersed on the AC also detected at $2 \theta=20.8^{\circ}$ as revealed in Fig. 4b. Referring to inset in Fig. 4bi, the broad peak of AC centered at $26.7^{\circ}$ was shifted to the left and increased intensity for the adsorbents containing 15 and $25 \mathrm{wt} \%$ of ODA. These diffraction changes are might be due to the promotion of higher ODA amount and interaction between then ODA and support.
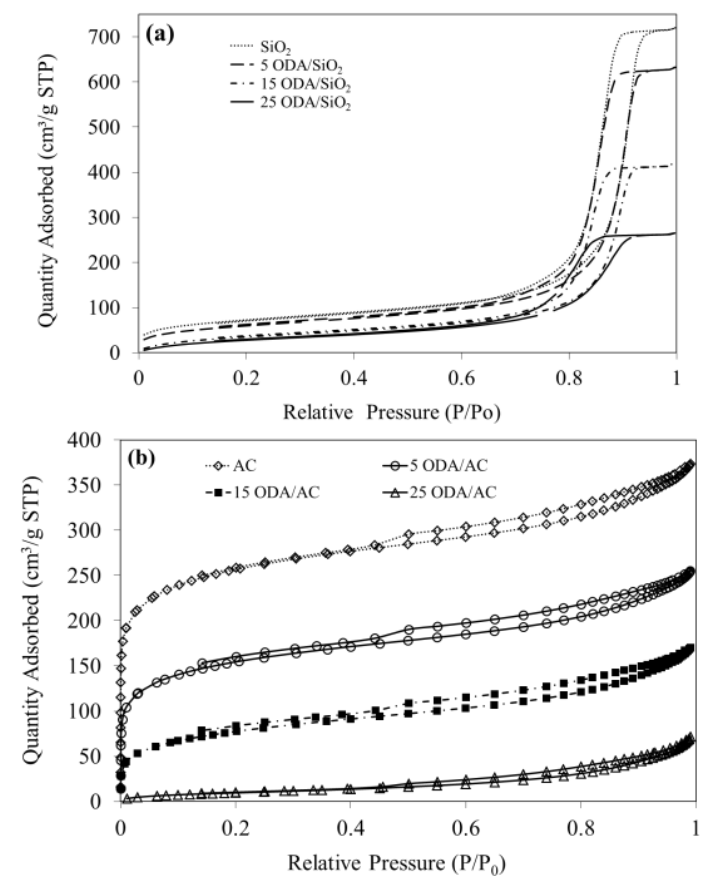

Fig. 5. BET analysis of $\mathrm{N}_{2}$ adsorption-desorption isotherms of (a) $\mathrm{SiO}_{2}$ and modified $\mathrm{SiO}_{2}$, and (b) $\mathrm{AC}$ and modified $\mathrm{AC}$.

\section{B. Nitrogen Adsorption - Desorption Isotherms}

The influence of the impregnation on the textural characteristics of the $\mathrm{SiO}_{2}$ and $\mathrm{AC}$ were evaluated through the analysis of the $\mathrm{N}_{2}$ adsorption-desorption isotherm at $77 \mathrm{~K}$. The $\mathrm{N}_{2}$ isotherms of $\mathrm{SiO}_{2}$ and ODA loaded $\mathrm{SiO}_{2}$ were classified as type IV adsorption-desorption with hysteresis loops as illustrated in Fig. 5a. Type IV isotherm exhibit a hysteresis loop, i.e., the adsorption and desorption isotherms do not overlap over a certain region of external pressure [22]. The isotherms show that $\mathrm{SiO}_{2}$ and amine loaded $\mathrm{SiO}_{2}$ are classified as mesopores adsorbents due to the type IV isotherm. Fig. $5 b$ is the $\mathrm{N}_{2}$ adsorption-desorption isotherm of AC and ODA loaded on AC. The features of these isotherms represent the type I curve according to the IUPAC classification. The physical properties of modified $\mathrm{SiO}_{2}$ such as the BET surface area, total pore volume, average pore width, micropore and external pore surface area are given in Table I. This studies show that the physical properties of modified $\mathrm{SiO}_{2}$ decreases with increases amount of ODA loaded. The modified AC exhibited similar surface properties as modified $\mathrm{SiO}_{2}$. Unfortunately, the average pore width of porous $\mathrm{AC}$ was contradictive with that trend.
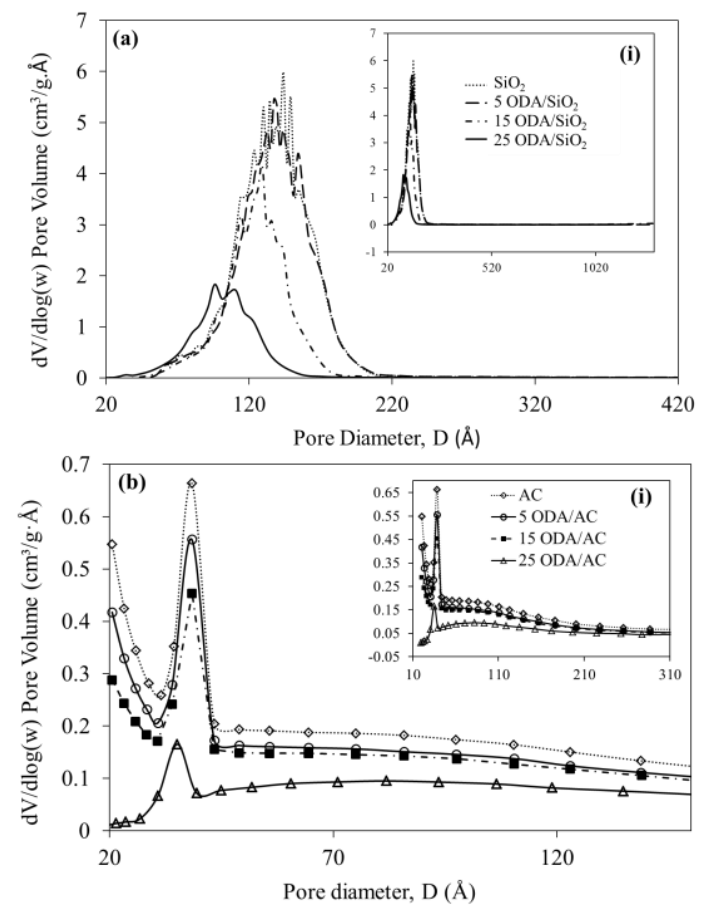

Fig. 6. Pore size distributions of $\mathrm{SiO}_{2}$ and modified $\mathrm{SiO}_{2}$ with (a) at range 20 $-420 \AA$, and (i) $20-1270 \AA$, followed by AC and modified AC with (b) $20-$ $80 \AA$, and (i) $10-310 \AA ̊$. Pore size distribution.

Fig. $6 \mathrm{a}$ and $6 \mathrm{~b}$ show the pore size distributions of modified and unmodified $\mathrm{SiO}_{2}$ and $\mathrm{AC}$ in which their pore diameter was measured in amstrong unit, $\AA$. The mesopores of $\mathrm{SiO}_{2}$ are mainly centered at $170.37 \AA$ whereas the modified $\mathrm{SiO}_{2}$ measured around 103.27 up to $155.89 \AA$. These prove that the decreasing pore size of all modified $\mathrm{SiO}_{2}$ is due to the present of ODA layer on the pore surfaces. Therefore, $\mathrm{SiO}_{2}$ adsorbents loaded with higher percentage of ODA (wt \%) possess the smaller pore size. Meanwhile, the pore size distributions for $\mathrm{AC}$ adsorbents were different from the $\mathrm{SiO}_{2}$ type adsorbents. The pore size of AC was slightly increased (refer to Table I) with increasing amount of ODA loaded. This proves that the impregnation produces a drastic decrease in the surface area and pore volume of $\mathrm{AC}$ due to the blockage of smaller pores by fatty amine as stated by [23]. Thus, the average pore diameter for $25 \mathrm{ODA} / \mathrm{AC}$ is referring to the bigger pores of $\mathrm{AC}$ that remained after the impregnation.

The cumulative pore volume curves in Fig. 7 show that the total pore volume is about $1.2 \mathrm{~cm}^{3} / \mathrm{g}$ and $0.33 \mathrm{~cm}^{3} / \mathrm{g}$ for $\mathrm{SiO}_{2}$ and AC. The pore size distributions show 1 peak for $\mathrm{SiO}_{2}$ $(170.37 \AA)$ and three peaks for AC centered at $97.20 \AA$ A 40.85 $\AA$ and $20.00 \AA$ which are corresponding to mesopores and large micropores respectively. This shows that the large micropores and mesopores are establish the porosity characteristics of $\mathrm{AC}$ whereas only mesopores could be ascertained the porosity of the $\mathrm{SiO}_{2}$. 


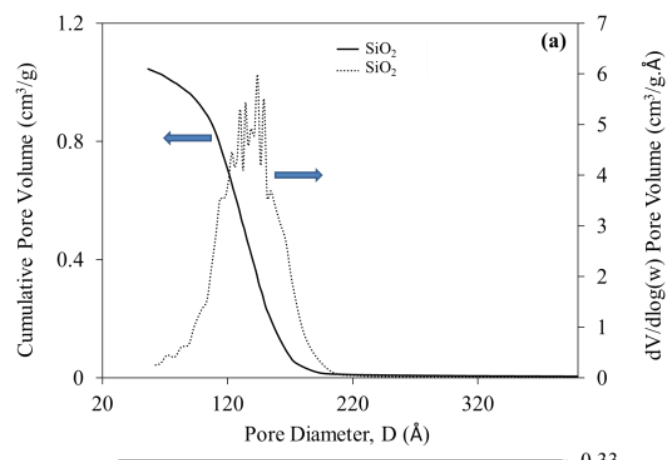

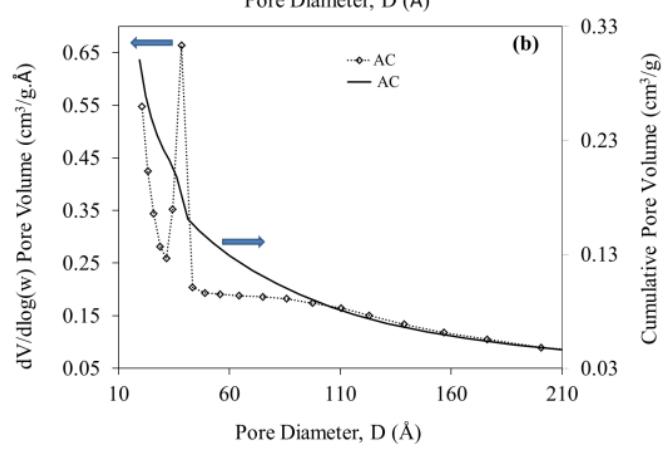

Fig. 7. Cumulative pore volume and pore size distribution of (a) $\mathrm{SiO}_{2}$ and (b) AC.

\section{C. $\mathrm{CO}_{2}$ Adsorption Capacity}

The effect of the impregnation on the adsorption capacity of $\mathrm{CO}_{2}$ of each sample was studied by using $\mathrm{CO}_{2}$ adsorption isotherms at $25{ }^{\circ} \mathrm{C}$ and $99.9 \% \mathrm{CO}_{2}$ as revealed in Fig. 8. In particular, silica modified with highest ODA showed high uptake of $\mathrm{CO}_{2}$ at low pressures (see Fig. 8). The high uptake values and weak temperature dependencies suggested chemisorptions of $\mathrm{CO}_{2}$ at low pressures [24]. Nonetheless, the isotherms were basically linear at high pressure suggestive of physisorption on both modified and unmodified.

Table II shows the $\mathrm{CO}_{2}$ adsorption capacity by the raw and modified porous materials. $\mathrm{SiO}_{2}$ with the highest ODA loading possess the best adsorption performance $(2.45 \mathrm{wt} \%$ $\mathrm{CO}_{2}$ /adsorbent) compared to other loading. This could be attributed to the presence of $25 \mathrm{wt} \%$ ODA which gave lowest pore area, pore volume, pore width of the $\mathrm{SiO}_{2}$ which provide numerous chemical adsorption sites for $\mathrm{CO}_{2}$ molecules and causes the formation of stronger $\mathrm{CO}_{2}-\mathrm{ODA}$ interaction in the $\mathrm{SiO}_{2}$ pore surfaces [23]. Modification of $\mathrm{SiO}_{2}$ surfaces by 5 wt $\%$ and 15 wt $\%$ ODA were not improving the $\mathrm{CO}_{2}$ uptake significantly (11.04 and $17.93 \mathrm{mg} \quad \mathrm{CO}_{2} / \mathrm{g}$ adsorbent) compared to $\mathrm{SiO}_{2}$ only ( $18.46 \mathrm{mg} \mathrm{CO} / \mathrm{g}$ adsorbent). One can be concluded that the $25 \mathrm{wt} \% \mathrm{ODA} / \mathrm{SiO}_{2}$ is the best adsorbent among $\mathrm{SiO}_{2}$ type adsorbents.

The piece of evidence that the raw AC presents the highest $\mathrm{CO}_{2}$ uptake capacity at room temperature is due to the higher involvement of physisorption. Conversely, this physisorption is restricted in the case of modified sorbents due to the empty large micropores being filled with the ODA molecules which influencing surface properties of AC. As a result, there is drastically decrease of their BET surface area and total pore volume as can be seen in Table I.

Modified AC showed lower $\mathrm{CO}_{2}$ adsorption capacity because of ODA molecules in the large micropores were difficult to interact with $\mathrm{CO}_{2}$ since the diameter of pores is too small and the long chain fatty amine producing steric hindrance effects. Consequently, the $\mathrm{CO}_{2}$ molecules were difficult to chemically interact with amine groups of the ODA compounds. Taken as a whole, we can summarize that the $\mathrm{CO}_{2}$ captured by the AC type adsorbents are basically via physisorption on the AC surfaces. Chemisorptions between ODA and $\mathrm{CO}_{2}$ molecules were not involved since the addition of ODA was significantly reduced the amount of $\mathrm{CO}_{2}$ captured.

TABLE II: COMPARISON OF $\mathrm{CO}_{2}$ ADSORPTION CAPACITY WITH VARIOUS

\begin{tabular}{|c|c|c|c|c|}
\hline Adsorbents & $\begin{array}{c}\text { Denotes } \\
\mathrm{SiO}_{2} \text { only }\end{array}$ & $\begin{array}{c}\mathrm{Max} . \mathrm{CO}_{2} \\
\text { Ads. [cm } / \mathrm{g}]\end{array}$ & $\begin{array}{c}\mathrm{Max} . \mathrm{CO}_{2} \\
\text { Ads. }[\mathrm{mg} / \mathrm{g}]\end{array}$ & $\begin{array}{c}\mathrm{Wt} \% \\
\mathrm{SO}_{2} \text { Ads. }\end{array}$ \\
\hline $\begin{array}{c}5 \mathrm{wt} \% \\
\mathrm{ODA} / \mathrm{SiO}_{2}\end{array}$ & $\begin{array}{c}5 \\
\mathrm{ODA} / \mathrm{SiO}_{2}\end{array}$ & 5.40 & 18.46 & 1.85 \\
\hline $\begin{array}{c}15 \mathrm{wt} \% \\
\mathrm{ODA} / \mathrm{SiO}_{2}\end{array}$ & $\begin{array}{c}15 \\
\mathrm{ODA} / \mathrm{SiO}_{2}\end{array}$ & 9.13 & 11.04 & 1.10 \\
\hline $\begin{array}{c}25 \mathrm{wt} \% \\
\mathrm{ODA} / \mathrm{SiO}_{2}\end{array}$ & $\begin{array}{c}25 \\
\mathrm{ODA} / \mathrm{SiO}_{2}\end{array}$ & 12.47 & 24.49 & 1.93 \\
\hline $\mathrm{AC}$ only & $\mathrm{AC}$ & 58.67 & 115.24 & 11.52 \\
\hline $\begin{array}{c}5 \mathrm{wt} \% \\
\mathrm{ODA} / \mathrm{AC}\end{array}$ & $5 \mathrm{ODA} / \mathrm{AC}$ & 21.06 & 41.37 & 4.14 \\
\hline $\begin{array}{c}15 \mathrm{wt} \% \\
\mathrm{ODA} / \mathrm{AC}\end{array}$ & $\begin{array}{c}15 \\
\mathrm{ODA} / \mathrm{AC}\end{array}$ & 11.52 & 22.63 & 2.26 \\
\hline $\begin{array}{c}25 \mathrm{wt} \% \\
\mathrm{ODA} / \mathrm{AC}\end{array}$ & $\begin{array}{c}25 \\
\mathrm{ODA} / \mathrm{AC}\end{array}$ & 6.85 & 13.46 & 1.34 \\
\hline
\end{tabular}

Max. $\mathrm{CO}_{2}$ Ads. $=$ Maximum $\mathrm{CO}_{2}$ uptake is given per gram adsorbent. Wt $\%$ $\mathrm{CO}_{2}$ Ads. $=$ Weight $\% \mathrm{CO}_{2}$ uptake per gram adsorbent.
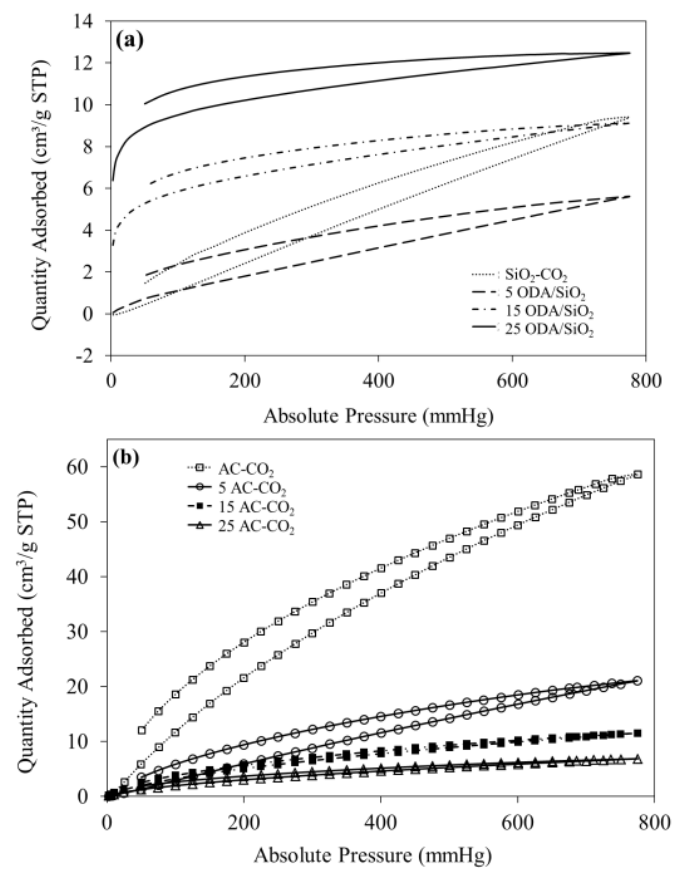

Fig. 8. $\mathrm{CO}_{2}$ adsorption capacity of (a) $\mathrm{SiO}_{2}$ and (b) $\mathrm{AC}$ with different $\mathrm{ODA}$ loading.

\section{CONCLUSION}

The addition of 25 wt \% ODA on the $\mathrm{SiO}_{2}$ surfaces affected the $\mathrm{CO}_{2}$ adsorption capacity by increasing $2.45 \%$ $\mathrm{CO}_{2} / \mathrm{g}$ adsorbent compared to $\mathrm{SiO}_{2}$ which only adsorbed $1.85 \% \mathrm{CO}_{2} / \mathrm{g}$ adsorbent and this is might due to chemisorptions between $\mathrm{CO}_{2}$ and ODA molecules. Meanwhile, ODA loaded on the AC were not improving the $\mathrm{CO}_{2}$ uptake capacity since the ODA addition causes the BET surface area, pore volume and micropore area of the $\mathrm{AC}$ were extremely reduced. It is clearly explain that addition of ODA was obviously constrained the physisorption between $\mathrm{CO}_{2}$ 
and AC. Hence, amine compounds with less bulkiness should be used as basic sites for $\mathrm{CO}_{2}$ capturing, minimizing the steric hindrance effect and reducing the pore blockage of the supporters.

\section{ACKNOWLEDGMENT}

Authors would like to thanks Ministry of Higher Education and Universiti Kebangsaan Malaysia for funding this project under research grant number BKBP-FST-K003323-2014, STGL-008-2012, ETP-2013-066, and Centre of Research and Innovation Management (CRIM) for the instruments facilities.

\section{REFERENCES}

[1] K. K. Pant and V. K. Srivastava, "Carbon dioxide absorption into monoethanolamine in a continuous film contactor," Chem. Eng. J., vol. 133, pp. 229-237, 2007.

[2] A. Samanta and S. S. Bandyopadhyay, "Absorption of carbon dioxide into aqueous solutions of piperazine activated," Chem. Eng. Sci., vol. 64, pp. 1185-1194, 2009.

[3] A. Anson, C. C. H. Lin, S. M. Kuznicki, and J. A. Sawada, "Adsorption of carbon dioxide, ethane and methane on titanosilicate type molecular sieves," Chem. Eng. Sci., vol. 64, no. 16, pp. 3683-3687, 2009.

[4] H. An, B. Feng, and S. Su, " $\mathrm{CO}_{2}$ capture by electrothermal swing adsorption with activated carbon fibre materials," Int. J. Greenh. Gas Control, vol. 5, no. 1, pp. 16-25, 2011.

[5] G. Zhao, B. Aziz, and N. Hedin, "Carbon dioxide adsorption on mesoporous silica surfaces containing amine-like motifs," Appl. Energy, vol. 87, no. 9, pp. 2907-2913, 2010.

[6] K. E. Zanganeh, A. Shafeen, and C. Salvador, " $\mathrm{CO}_{2}$ capture and development of an advanced pilot-scale cryogenic separation and compression unit," Energy Procedia, vol. 1, no. 1, pp. 247-252, 2009.

[7] A. Brunetti, F. Scura, G. Barbieri, and E. Drioli, "Membrane technologies for $\mathrm{CO}_{2}$ separation," J. Memb. Sci., vol. 359, pp. 115-125, 2010 .

[8] J. Liu and R. Lin, "Structural properties and reactivities of amino-modified silica fume solid sorbents for low-temperature $\mathrm{CO}_{2}$ capture," Powder Technol., vol. 241, pp. 188-195, 2013.

[9] S. C. Lee, C. C. Hsieh, C. H. Chen, and Y. S. Chen, " $\mathrm{CO}_{2}$ adsorption by Y-type zeolite impregnated with amines in indoor air," Aerosol Air Qual. Res., vol. 13, pp. 360-366, 2013.

[10] X. Liu, L. Zhou, X. Fu, Y. Sun, W. Su, and Y. Zhou, "Adsorption and regeneration study of the mesoporous adsorbent SBA-15 adapted to the capture/separation of $\mathrm{CO}_{2}$ and $\mathrm{CH}_{4}$," vol. 62, pp. 1101-1110, 2007.

[11] X. Xu, C. Song, J. M. Andresen, B. G. Miller, and A. W. Scaroni, "Preparation and characterization of novel $\mathrm{CO}_{2}$ : Molecular basket adsorbents based on polymer-modified mesoporous molecular sieve MCM-41," vol. 62, pp. 29-45, 2003.

[12] M. S. Shafeeyan, W. Mohd, A. Wan, A. Houshmand, and A. Arami-niya, "The application of response surface methodology to optimize the amination of activated carbon for the preparation of carbon dioxide adsorbents," Fuel, vol. 94, pp. 465-472, 2012.

[13] N. Isa, W. J. N. Fernando, M. R. Othman, and A. L. Ahmad, "Studies on adsorption/desorption of carbon dioxide with respect to thermal regeneration of hydrotalcite," in Proc. Int. Conf. Environ. (ICENV 2008), pp. 1-8, 2008.

[14] J. J. Benítez and M. Salmeron, "Structure and Chemical State of octadecylamine self-assembled monolayers on mica," J. Phys. Chem., vol. 115C, pp. 19716-19723, 2011.

[15] R. A. MacPhail, H. L. Strauss, R. G. Snyder, and C. A. Elliger, "Carbon-hydrogen strecthing modes and the structure of n-alkyl chains 2. Long, all-trans chains," J. Phys. Chem, vol. 88, no. 3, pp. 334-341, 1984.

[16] L. J. Bellamy, The Infrared Spectra of Complex Molecules, 2nd ed., Wiley New York, 1980, pp. 21-26.

[17] H. Yamada, F. A. Chowdhury, K. Goto, and T. Higashii, " $\mathrm{CO}_{2}$ solubility and species distribution in aqueous solutions of 2 (isopropylamino) ethanol and its structural isomers," Int. J. Greenh. Gas Control, vol. 17, pp. 99-105, 2013.

[18] C. Pevida, M. G. Plaza, B. Arias, J. Fermoso, F. Rubiera, and J. J. Pis, "Applied Surface Science Surface modification of activated carbons for $\mathrm{CO}_{2}$ capture," Appl. Surf. Sci., vol. 254, pp. 7165-7172, 2008.
[19] G. Qi, Y. Wang, L. Estevez, X. Duan, N. Anako, A.-H. A. Park, W. Li, C. W. Jones, and E. P. Giannelis, "High efficiency nanocomposite sorbents for $\mathrm{CO}_{2}$ capture based on amine-functionalized mesoporous capsules," Energy Environ. Sci., vol. 4, no. 2, pp. 444-452, 2011.

[20] W. Hammond, E. Prouzet, S. D. Mahanti, and T. J. Pinnavaia, "Structure factor for the periodic walls of mesoporous MCM-41 molecular sieves," Microporous Mesoporous Mater., vol. 27, pp. 19-25, 1999.

[21] J. Sauer, F. Marlow, and F. Schu, "Simulation of powder diffraction patterns of modified ordered mesoporous materials," Phys. Chem, vol. 3, pp. 5579-5584, 2001.

[22] T. Sakpal, A. Kumar, S. Kamble, and R. Kumar, "Carbon dioxide capture using amine functionalized silica gel," Indian J. Chem., vol. 51A, pp. 1214-1222, 2012.

[23] M. N. Abu Tahari and M. A. Yarmo, "Adsorption of $\mathrm{CO}_{2}$ on silica dioxide catalyst impregnated with various alkylamine," in Proc. 2014 UKM FST Postgrad. Colloq. AIP Conf. Proc., 2014. vol. 1614, pp. 334-341.

[24] Z. Bacsik, N. Ahlsten, A. Ziadi, G. Zhao, A. E. G. Bennett, B. Martin-Matute, and N. Hedin, "Mechanisms and kinetics for sorption of $\mathrm{CO}_{2}$ on bicontinuous mesoporous silica modified with n-propylamine," Langmuir, vol. 27, pp. 11118-11128, 2011.

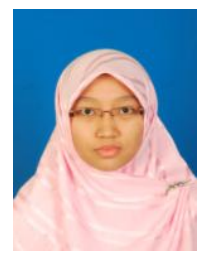

Maratun Najiha Abu Tahari obtained her BSc. in science (oleochemistry) from Universiti Kebangsaan Malaysia on 2012. She is currently doing master degree in chemistry at School of Chemical Sciences and Food Technology, Faculty of Science and Technolgy, Universiti Kebangsaan Malaysia (UKM) from 2012 to 2015.

She experienced works in synthesis biolubricant based on diesters from 2011 to 2012. She was a laboratory demonstrator at UKM before being offered as a part timer chemistry teacher at Pusat Permata Pintar, UKM in 2015. Her research interests are in the field of fatty amine development for $\mathrm{CO}_{2}$ capturer application.

Maratun Najiha Abu Tahari was awarded with Public Service Department (JPA) Scholarship from Malaysian Government during her bachelor study. She had won silver medal award for poster presentation during International Conference of Postgraduate Education ICPE-6 2014. She also owned several publications related to the $\mathrm{CO}_{2}$ capturing study.

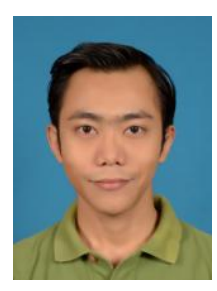

Azizul Hakim Bin Lahuri is a Ph.D candicate of second year in chemistry from Universiti Kebangsaan Malaysia. He received BSc. in chemistry from Universiti Kebangsaan Malaysia in 2009 and master degree in environment from Universiti Putra Malaysia in 2012. He was born on July $28^{\text {th }} 1987$ at Pasir Gudang, Johor Bahru, Johor.

His research interests are reduces anthropogenic gas of carbon dioxide $\left(\mathrm{CO}_{2}\right)$ by investigate the adsorption and desorption properties. He is conducting the research by using commercial and synthesized solid adsorbents that have potential in $\mathrm{CO}_{2}$ capturing. His worked experiences in academic nor industry as a level chemistry lecturer in Kolej Teknologi Timur and environmental executive in environmental science (M) Sdn. Bhd., were the advantages in his research. He is currently working as part time tutor in Universiti Putra Malaysia and laboratory tutor in Inti International College Subang.

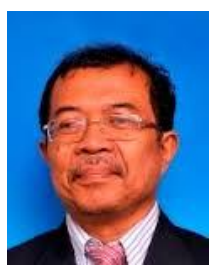

Mohd. Ambar Yarmo received his BSc in chemistry from Universiti Kebangsaan Malaysia (UKM) and his Ph.D in analytical chemistry from University Of Wales, Cardiff, U.K. He was born at Johor, Malaysia.

His research interests are in conversion of $\mathrm{CO}_{2}$ to Fuel, bio-ethanol derivatives and biofuel applications, upgrading of natural gas and palm oil to higher added value speciality chemicals using combinatorial technologies and catalysis. He has attended to Japanese scientific exchange programme under JSPS-VCC programme in 1988. He was a visiting scientist at Petronas Research and scientific services in 1995. He has research collaboration with Fritz Haber Institute, Max Planck Society, Berlin, Germany in 2002.

He was the outstanding UKM lecturer in research and teaching in 2000, 2002 and 2005. He is the chairman of Xapp-MNS (X-ray Application Society), Malaysian Nuclear Society. He is a senior member of International Zeolite Association (IZA, USA), Malaysian Analytical Member Society (ANALIST) and Malaysian Nuclear Society. 